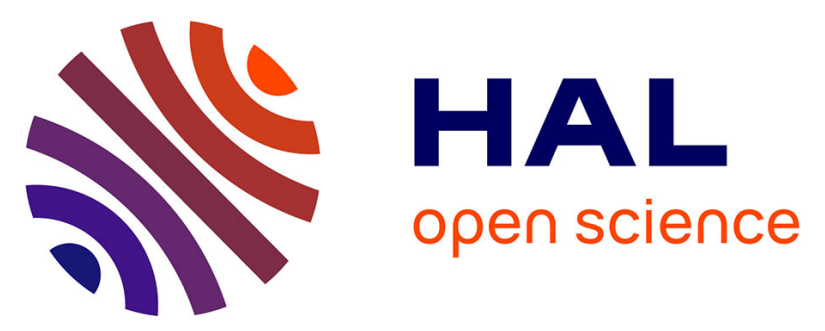

\title{
Non-invasive X-ray investigations of medieval sculptures: New insights on "applied tin-relief brocade" technique
}

Pauline Martinetto, Nils Blanc, Pierre Bordet, S. Champdavoine, F. Fabre, T. Guiblain, J.-L. Hodeau, F. Lelong, O. Leynaud, A. Prat, et al.

\section{- To cite this version:}

Pauline Martinetto, Nils Blanc, Pierre Bordet, S. Champdavoine, F. Fabre, et al.. Non-invasive X-ray investigations of medieval sculptures: New insights on "applied tin-relief brocade" technique. Journal of Cultural Heritage, 2021, 47, pp.89-99. 10.1016/j.culher.2020.10.012 hal-03025355

\section{HAL Id: hal-03025355 \\ https://hal.science/hal-03025355}

Submitted on 26 Nov 2020

HAL is a multi-disciplinary open access archive for the deposit and dissemination of scientific research documents, whether they are published or not. The documents may come from teaching and research institutions in France or abroad, or from public or private research centers.
L'archive ouverte pluridisciplinaire HAL, est destinée au dépôt et à la diffusion de documents scientifiques de niveau recherche, publiés ou non, émanant des établissements d'enseignement et de recherche français ou étrangers, des laboratoires publics ou privés. 


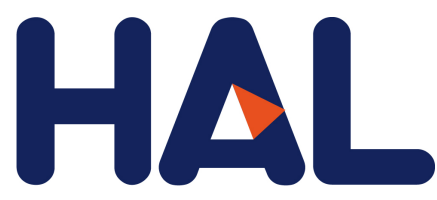

archives-ouvertes

\title{
Non-invasive X-ray investigations of medieval sculptures: New insights on "applied tin-relief brocade" technique
}

\author{
Pauline Martinetto, N. Blanc, Pierre Bordet, S. Champdavoine, F. Fabre, T.
} Guiblain, J.-L. Hodeau, F. Lelong, O. Leynaud, A. Prat, et al.

\section{To cite this version:}

Pauline Martinetto, N. Blanc, Pierre Bordet, S. Champdavoine, F. Fabre, et al.. Non-invasive X-ray investigations of medieval sculptures: New insights on "applied tin-relief brocade" technique. Journal of Cultural Heritage, Elsevier, 2020, 10.1016/j.culher.2020.10.012 · hal-03025355

\section{HAL Id: hal-03025355 \\ https://hal.archives-ouvertes.fr/hal-03025355}

Submitted on 26 Nov 2020

HAL is a multi-disciplinary open access archive for the deposit and dissemination of scientific research documents, whether they are published or not. The documents may come from teaching and research institutions in France or abroad, or from public or private research centers.
L'archive ouverte pluridisciplinaire HAL, est destinée au dépôt et à la diffusion de documents scientifiques de niveau recherche, publiés ou non, émanant des établissements d'enseignement et de recherche français ou étrangers, des laboratoires publics ou privés. 


\title{
Non-invasive X-ray investigations of medieval sculptures: New insights on "applied tin-relief brocade" technique
}

\author{
P. Martinetto ${ }^{a}, *$, N. Blanc ${ }^{a}$, P. Bordet ${ }^{a}$, S. Champdavoine ${ }^{b}$, F. Fabre $^{b}$, T. Guiblain $^{b}$,

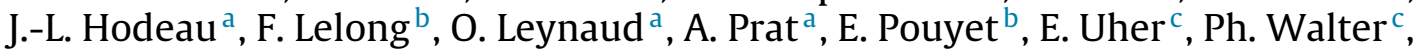 \\ In memory of Hélène Rousselière
}

a Univ. Grenoble Alpes, CNRS, Institut Néel, 38000, Grenoble, France

${ }^{\mathrm{b}}$ ARC Nucléart, CEA, 38000, Grenoble, France

' Sorbonne Université, CNRS UMR 8220, LAMS, Paris cedex 05, France

\section{A R T I C L E I N F O}

\section{Article history:}

Received 4 June 2020

Accepted 29 October 2020

Available online $\mathrm{xxx}$

\section{Keywords:}

Applied brocade

Non-invasive

Portable instrument

Diffraction

Fluorescence

\begin{abstract}
A B S T R A C T
Two polychrome sculptures from the late Middle Age were investigated by means of non-invasive techniques with the aim of characterizing sophisticated relief decoration named "applied brocade". Here, we have used portable instrumentation solely in order to perform X-ray powder diffraction and fluorescence measurements at the surface of the sculptures. The results show a reliable localisation and identification of the different materials making up an applied brocade: a filler material, a tin-based foil and a gilding, even in the case of a largely overpainted sculpture. More particularly, a direct identification of the organic material used for the filler as natural beeswax is proposed. Differences between the two investigated artworks have also been identified: (i) in the structure of the calcium sulphate preparation layers (one or double layer of gesso) (ii) in the presence or absence of a priming paint layer under decors (iii) in the choice of the material used to make the gilding: pure gold or probable zwischgold. The characterization of the degradation of this type of decorations was also assessed, namely romarchite ( $\mathrm{SnO}$ ) and cassiterite $\left(\mathrm{SnO}_{2}\right)$ were identified and their relative proportion estimated.
\end{abstract}

\section{Introduction and research aim}

History of art and techniques has long come up against a difficulty: the impossibility of studying the materials used by artists of the past without moving their works or taking samples. However, over the last twenty years or so, mobile instruments have been developed, allowing art objects to be analysed wherever it is located (museum, archaeological site, etc.). First attempts to work outside the laboratory were performed using portable fibre optic UV-visNIR reflectance spectroscopy and Raman spectroscopy [1,2]. X-ray fluorescence spectroscopy (XRF) has also a long history and since 2005, the use of hand-held devices, traditionally developed for geology, for recycling industry or as a detection tool for lead paint in housing, has exploded in the field of archaeology [3]. However, objects investigated in art and archaeology present generally complex 3-dimensional surfaces. Therefore, they rapidly motivated the growth of in-house-built instruments with independent miniatur-

* Corresponding author at: Univ. Grenoble Alpes, CNRS, Institut Néel, 25, avenue des Martyrs BP166, 38042 Grenoble Cedex 9, 38000, Grenoble, France.

E-mail address: pauline.martinetto@neel.cnrs.fr (P. Martinetto). ized X-ray tube and detector, allowing more versatile positioning to couple with changes in detection geometry. Originally designed for single spot analysis, portable XRF instruments have recently been modified to allow scanning large areas of the works of art, providing elemental distribution images. However, XRF imaging is mostly restricted to " $2 \mathrm{D}$ objects", as the measurement head is usually moved in a plane parallel to the studied surface. We can cite as examples application to historical paintings, which have the great advantage to present a flat surface [4,5], stained-glass windows, illuminated manuscripts, antique polychromy [6,7] Several authors propose also to combine elemental and vibrational imaging techniques to achieve a more complete chemical description of the artwork surfaces [8-11]. However, these spectroscopic techniques may fail to distinguish materials with the same elemental/molecular composition but different crystalline structures. For that reason, several groups have developed portable systems to perform in situ measurements by X-ray powder diffraction (XRPD), the most reliable technique for identifying crystalline materials: the potential power of these systems in cultural heritage applications was recently reviewed and the characteristics of each system were compared [12]. Most of these systems propose a joint use of 
XRPD and XRF [13-16], even if several severe geometrical requirements have to be fulfilled for the collection of diffraction data (fixed geometry between the X-ray tube, the artwork surface and the detector). Despite limitations due to the difference of probed volume for both techniques (which varies with the geometry and the energy of the X-rays) and a spatial resolution which may be larger than the sample stratigraphy, this type of instrument has been successfully used to study painted surfaces kept in museums, churches, or ancient buildings, more rarely in other environments (prehistoric cave: [17]; Ramesside tomb in Egypt [9]). Very recently, efforts have been made to build scanning XRPD systems, both in transmission and reflection mode, but they are currently limited to flat objects: illuminated manuscripts and masters' paintings $[18,19]$.

\subsection{The applied brocades}

In the present article, we performed combined XRF/XRPD measurements on "3D objects", i.e. polychrome sculptures, which remains challenging. Our aim was to propose an exhaustive in-situ approach to analyse and characterize polychromy in a non-invasive way. We focused our analyses on a form of relief decoration whose basic component is generally a sheet of tin foil pressed into a mould previously incised with the decorative pattern. This technique, called "applied brocade", proved to be a very convincing illusionistic polychromy technique to imitate silk fabrics enriched with gold and silver, created by textile craftsmen in Italy in the 15th and 16 th centuries. It is probably based on a long-lasting tradition of tin work [20], metal used since Antiquity and often preferred to other metals for its physical and mechanical properties ( $\beta$-tin, the stable form at room temperature has a low melting point, is malleable and keeps its metallic appearance with time). However, even if the production of thin tin foils and their use instead of silver or gold for manuscript illumination is mentioned by Theophilus Presbyter as early as the 12th century [21], the techniques allowing the manufacture of polychromed tin foil-based relief has been passed on in few written sources. Two ancient texts dating from the late Middle Ages: Il libro dell'arte [22] and Liber illuministarum or "Tegernsee Manuscript" [23], are nowadays considered to give the most relevant recipes [24]. They describe the fabrication process of ready-made polychromed brocades which can be simplified and summarized in 5 steps:

1 Press a sheet of tin foil into an incised mould

2 Spread a pasty material on the tin foil to fill in the hollows until a flat surface is reached

3 Once the filler is dry, demould

4 Attach to the surface to be decorated

5 Gild and/or paint the surface of the moulded tin foil sheet (this step can be done before or after application to the surface).

Applied brocades went unstudied and unregarded until their first identifications on artworks and their technical analysis in the 1960s and 1970s [25]. There are few examples of well-preserved applied brocades. On the one hand, they are unsound due to their manufacture and on the other hand, some may have been not preserved during restorations, poorly identified due to a lack of knowledge about this form of decoration. Although there are some examples of 14th century sculptures decorated with applied brocade, the technique became fairly common in European art from the early 15 th century and remained so for over a century before fallen out of favour by the mid-16th century [26,27]. Several case studies on sculptures [28-31] panel paintings [25,26,29,32-38]; but also on wall paintings [29,39-41] and architectural polychromy [29] are described in literature. The most exhaustive project of inventory, classification and study, both technical and stylistic, has been carried out for 86 works produced in the Low Countries between 1350 and 1550 and now kept in Belgian collections [29]. Review papers for other geographical area have been also published: Northern Spain [34], Transylvania [37] and for works from French collections [31,42]. All these studies show that the overall layered structure of the brocades is consistent with that described in ancient texts, but also highlight variations that could reflect specific know-how of some workshops. Tracking the fabrication process of applied brocades through late-medieval culture can therefore help to better understand the diffusion of the technique throughout Europe and hence, the trade routes and the organisation of networks of artists and craftsmen during this period.

The study presented in this paper is a part of an ongoing interdisciplinary project, which aims at an exhaustive examination and inventory of applied brocade in 15th and 16th century Savoy Duchy [42-44]. This project has two complementary components: on one hand, a visual observation of the applied brocade in order to propose a description of the decorative patterns (which are often very incomplete) and the other hand, the physico-chemical analysis of the various layers of the applied brocade in order to identify the constituting materials. It will enlarge the current knowledge on the applied brocade technique by providing technical elements for a geographical area that has never been studied before. It will also contribute to a better characterization of the degradation products of these precious decors, which could help developing adapted conservation strategies. Here, we focus on the study of two polychrome carved groups related to the ancient Savoy Duchy and dated to the beginning of the 16th century by using a portable non-invasive XRPD/XRF instrument. The aim of this work is to highlight the potential of non-invasive approaches to provide a reliable description of the applied brocades stratigraphy while minimizing sampling.

\section{Material and methods}

\subsection{Presentation of the sculptures}

Recently, on the occasion of conservation-restoration works conducted on several polychrome sculptures related to the ancient Savoy Duchy of the late Middle Ages, remnants of applied brocades were discovered $[43,44]$. These sculptures have been connected to a group of about forty works, consistent both in style and iconography, produced over a few decades between 1480 and 1530 . Existence of such a corpus is testament to the activity of local sculptors and the presence of several artists' workshops [45]. These elements motivated an exhaustive examination and inventory of applied brocade in 15th and 16th century Savoy Duchy in order to identify the techniques and materials used for its manufacturing, provide new evidences on local workshop practices and determine the influence of this geographical area, which was an important route of transit and exchange in Europe due to its strategic position. Both studied sculptures are painted wood Pietà, dated to the end of the 15th century or the beginning of the 16th century, depicting a sorrowful Virgin Mary, surrounded by Saint John and Saint Mary Magdalene, accompanying her after the Crucifixion of Christ, when he is taken down from the cross and laid, dead on her knees. The first sculpture (called Pietà SO in the following) has been discovered in the church of Saint-Offenge (Savoie, France) (Fig. 1a). It was classified as part of the French national heritage in 1952 and is currently kept in the Musée savoisien in Chambéry (Savoie, France). The small figure kneeling at the front represents a donor wearing a Saint Antony Order's garment, which provides information on the origin of the sponsor [46]. Remnants of relief decors are still visible in different zones on the garments of the figures: Saint John's man- 

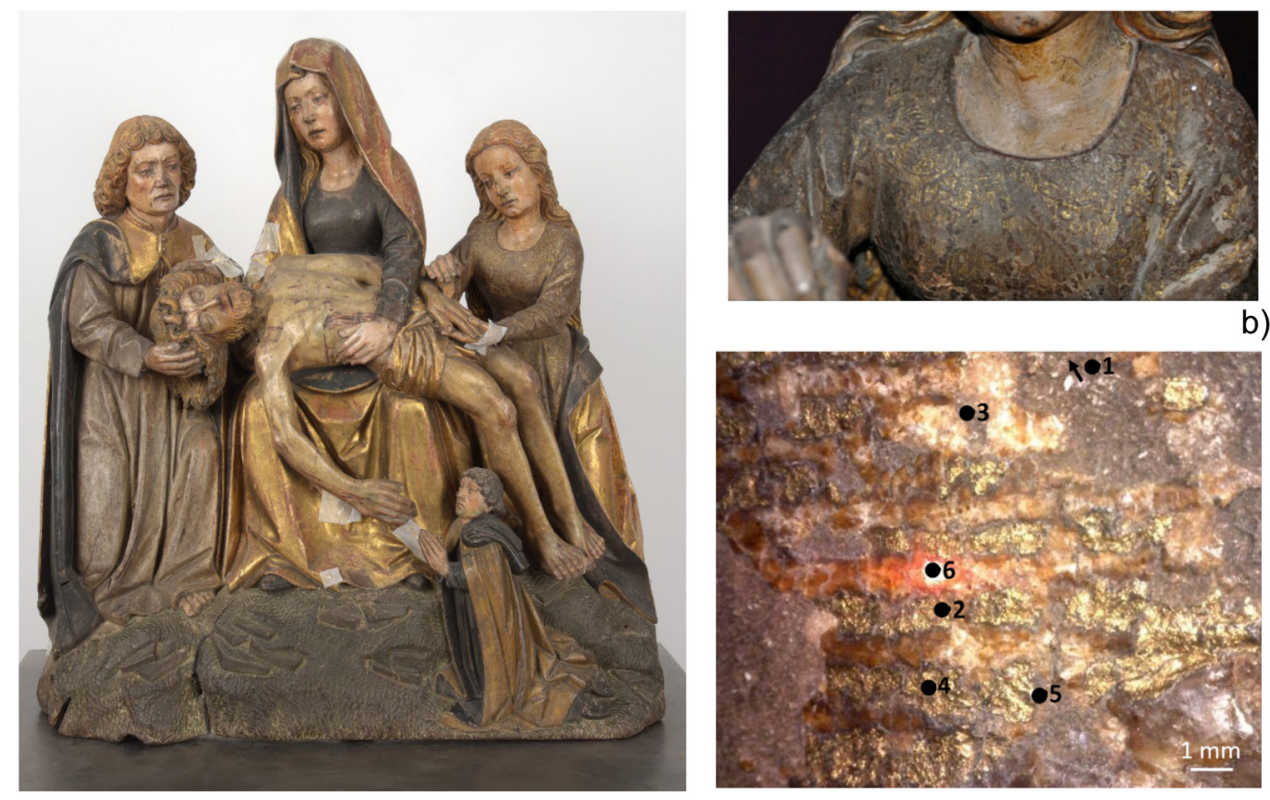

b)

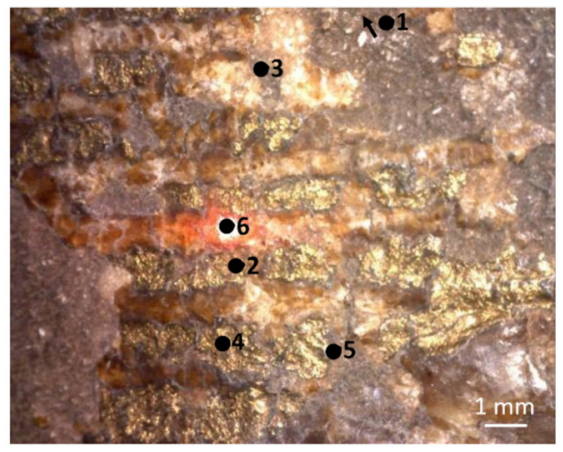

a)

C)

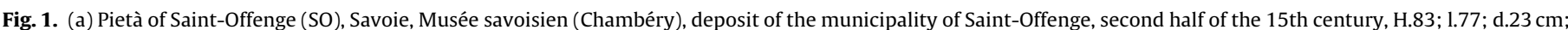

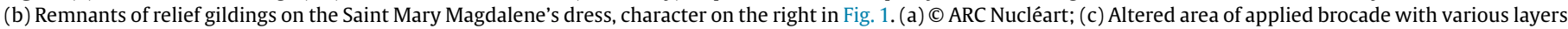

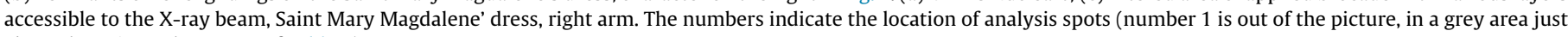
above, laser is on the spot 6 , cf Table 1 ).

tle, Virgin's dress, and Saint Mary Magdalene's dress, these latter being the best preserved (Fig. 1b).

The second sculpture analysed (Pietà MON) is part of the collection of the castle of Montrottier (inv. 2349) in Lovagny (HauteSavoie, France) (Fig. 2a), classified as part of the French national heritage in 1995 . Only a very careful observation of the sculpture may suggest that relief decorations are present because they are covered by overpainting (Fig. 2 b). It seems that all the garments were decorated.

\subsection{Non-invasive XRPD-XRF measurements}

XRD-XRF measurements were performed using a portable XRD-XRF instrument, named DiffiX, designed and constructed by the Laboratory of Molecular and Structural Archaeology (LAMS, Sorbonne Université/CNRS, Paris). It is the latest version of an instrument developed and optimised over the past 10 years $[13,16]$ that has been successfully applied to numerous studies of painted artistic surfaces $[47,48]$. For this project, the instrument was mounted on an adjustable tripod (in height and angle) so that it could be correctly oriented in relation to the sculptures (Fig. 3a). XRF and XRPD were carried out at the same point of the artwork with an incident beam at about $6-10^{\circ}$ from the object surface. The point where the X-rays beam impinges the surface is located using a laser pointer (aligned on the X-ray beam axis) and a telemeter (which measures the distance perpendicular to the beam). The instrument is built with an air-cooled X-ray tube (Xenocs, Grenoble) with a copper anode $(\mathrm{Cu}-\mathrm{K} \alpha, \mathrm{E}=8.04 \mathrm{keV})$. The attenuation length is about $85 \mu \mathrm{m}$ for a material composed of light elements ( $\mathrm{Al}$, $\mathrm{Si}, \mathrm{K}, \ldots$ ) and $5 \mu \mathrm{m}$ for heavy elements (Pb, Hg, Sn, ...). This X-ray source is equipped with a multi-layered optics (Xenocs, Grenoble), providing a beam with a spot size of $200 \mu \mathrm{m}$ FWHM and a flux of $1,50.10^{8}$ photons per second. A photostimulable imaging plate (usually used in dental imaging) is placed perpendicular to the incident beam to record the 2D diffraction signal over an exposure time of approximatively $20 \mathrm{~min}$, before being scanned with a Vistascan scanner to obtain the diffraction image. The software FIT2D [49] or
PyFAI [50] is used to convert the diffraction images into 1D XRPD patterns (intensity versus $2 \theta$ ). Calibration of the distance sampledetector, and the orthogonality of the detector to the incident beam was achieved using an $\mathrm{Al}_{2} \mathrm{O}_{3}$ standard put to the place of the sculpture. DIFFRAC.EVA's (Bruker) search/match module, which performs searches on the PDF4+ (2018) reference database, has been used for crystalline phase identification. Rietveld refinements were conducted with the Fullprof_Suite [51] to obtain the mass proportion of the different crystalline phases present at the analysed point, when necessary and when allowed by data quality. The Inorganic Crystal Structure Database [52] has been consulted to obtain the crystal structures of the identified phases. XRF is measured with a SDD (silicon drift detector, Amptek, active area of $25 \mathrm{~mm}^{2}$ ), perpendicular to the object. This system also includes another more energetic $\mathrm{X}$-ray source (Moxtek, Orem, USA) with a palladium anode (Pd-K $\alpha$, $\mathrm{E}=21.12 \mathrm{keV}$ ), placed above the SDD detector. This source emits a beam with a larger spot size (in the order of $\mathrm{mm}$ ) but allows the detection of elements with higher atomic number $Z$. At each point, two 5-minute XRF measurements have thus been performed: one using the copper tube to detect elements with $13(\mathrm{Al})<\mathrm{Z}<29$ (Cu) (low energy X-rays emitted by light elements with $Z<13$ are completely absorbed by the air slab between the object and the detector), the other using the palladium tube to detect elements with $13<\mathrm{Z}<46$ (Pd). All the XRF spectra were processed with the PyMca software [53]. Only qualitative analysis has been attempted: XRF data provides the elemental chemical composition of the different probed points and this latter is used as a selection criterion for the phase search in the PDF-4+ database to identify the crystalline phases. XRF data were also used to estimate the thickness of some layers in the stratigraphy. Attenuation of the intensity of an X-ray beam as it passes through matter is described by the exponential attenuation law:

$I=I_{0} e^{(-\mu \rho x)}$

where $I$ is the beam intensity after attenuation, $I_{0}$ is the beam intensity prior to attenuation, $x$ is the thickness of the material, $\rho$ is the density of the material and $\mu$ is the mass attenuation coefficient for 


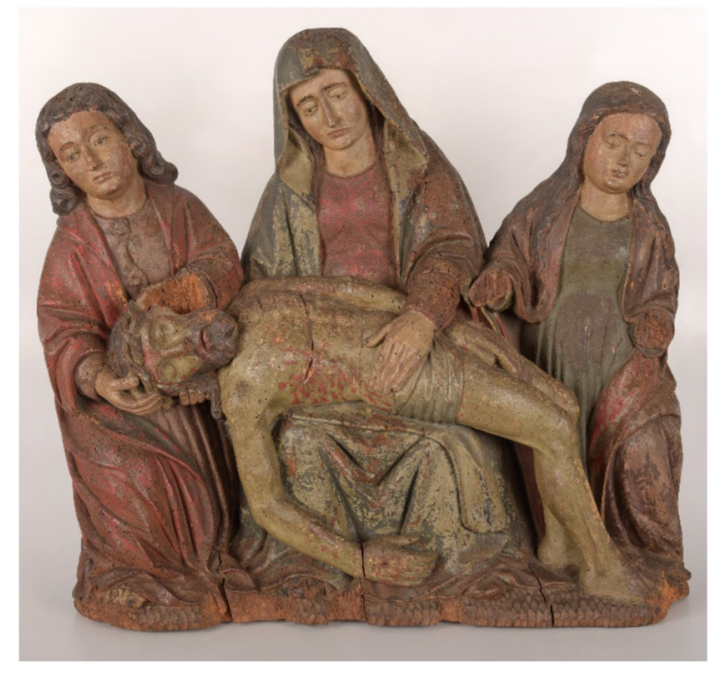

a)

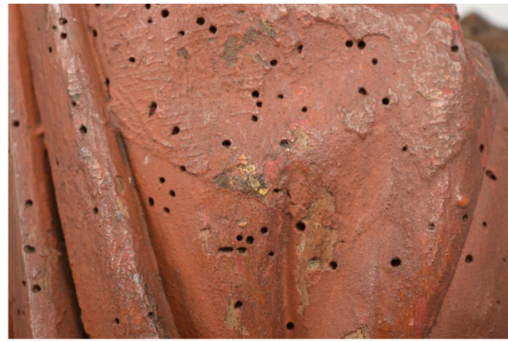

b)

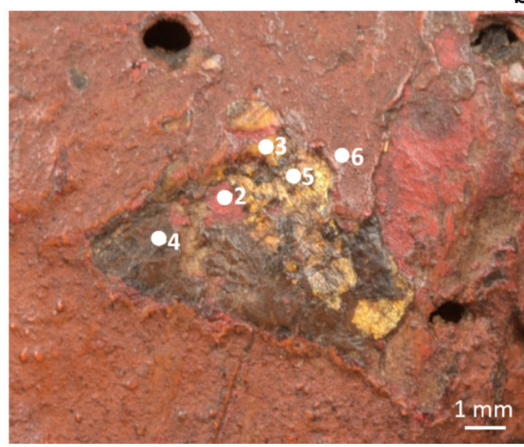

C)

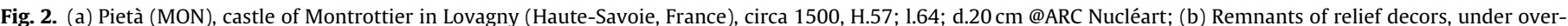

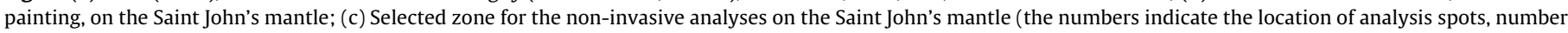
1 is out of the picture, cf Table 2).

the material at a given X-ray energy [54]. The exponential attenuation law can therefore easily be used to calculate the attenuation effect of a layer of known composition.

\section{Results}

\subsection{Visual observation of the polychromy and selection of the probed zone}

As mentioned above, concerning the Pietà SO, the best preserved remains of applied light relief decorations can be found on the dress of Saint Mary Magdalene. Here, the decoration covers the whole garment, which corresponds to the definition of a continuous applied brocade where pressed tin foil sheets were glued onto the support edge to edge to reproduce an entire fabric [55]. Concerning the Pietà MON, remnants of relief decors are very difficult to see even if traces can be guessed on all garments, underneath the overpainting. We focused on the decors found on the Saint John's mantle: here, the presence of local applied brocade is suspected because polygona sheets appear to have been trimmed and arranged at regular intervals on the surface. For both sculptures, a very careful observation of the decorated zones revealed flaws in the polychromies: these zones were chosen for the non-invasive analyses because the various layers of the stratigraphy become accessible to the X-ray beam (Figs. 1c and 2c), even in the case of strongly absorbing top layers, such as lead containing overpaintings.

\subsection{Pietà SO}

Six spot analysis have been performed on the chosen zone (Fig. 1c) and reveal different chemical and structural compositions. XRF/XRPD results are summarized Table 1 . XRF fit and phase identification for spot 6 are given Fig. 3b, Figs. S3 and S1 (Supplementary Information).

Only spot 1 has a different chemical composition as it contains no tin $(\mathrm{Sn})$, no gold $(\mathrm{Au})$ and very little lead $(\mathrm{Pb})$ : the other points all contain the same elements but with different ratios. For exam- ple, Fig. S2 (in Supplementary Information) shows the variations for calcium (Ca) and tin. Spots 5 and 6 are the richest in tin and gold. Concerning the structural composition, the number of identified crystalline phases goes from 3 (spot 1 ) to 8 (spots 5 and 6). The nature of the identified compounds is consistent with chemical composition: in addition to Ca-rich minerals, spots 5 and 6 contains Sn-based phases (romarchite and cassiterite), gold and minium. Minium, like other pigments containing copper $(\mathrm{Cu})$ and iron ( $\mathrm{Fe})$, may have been added to beeswax to form a lightly coloured filler and/or to speed up its drying [56,57]. These pigments could also be present in a very thin layer covering the tin foil corresponding to a glaze or a mordant for the leaf gold. The low concentration of these pigments or their non-crystalline state could explain why no $\mathrm{Cu}$ - or Fe-based phase was detected by XRPD. Here, the very poor state of conservation of the decors makes it difficult to describe the visual appearance and the colour of the filler. However, by combining the non-invasive results with the previously visual observation of the decorated zones, each spot analysis can be related to a layer of the stratigraphy:

- Spot 1, which corresponds to the deepest layer, contains mainly anhydrite and may be identified as a preparation layer (layer 1 ),

- Spots 2-4, which correspond to a layer (layer 2) deposited on the preparation layer, are rich in beeswax, a material commonly used as a filler,

- Spots 5 and 6 correspond to data collected on the outer layer (layer 3): they show, in addition to the materials of the layers 1 and 2 , the presence of two tin oxides, gold and a small amount of minium.

A possible stratigraphy is suggested in Fig. 5.

To sum up, all characteristic materials of applied brocade are thus met: a filler material and a tin foil covered with gold leaf (metallic tin being degraded to oxides).

\subsubsection{Identification of the filler}

In previous works, identification of organic compounds of the fillers, the fill materials intended to reinforce the stamped 

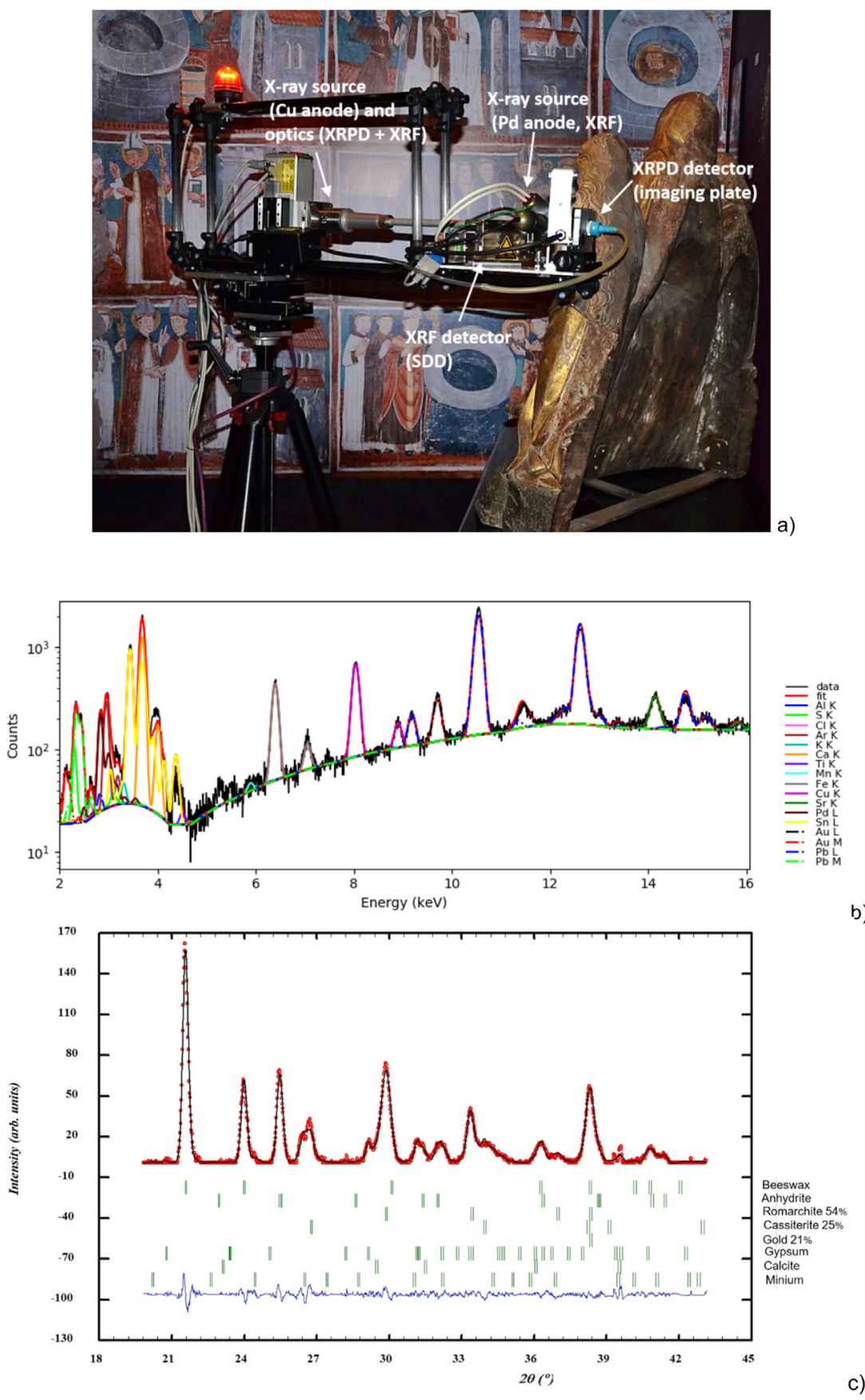

Fig. 3. (a) Mobile instrument in front of the Pietà SO; XRF and XRPD results for spot 6: (b) XRF fit, Pd source (a selection in the energy range 2.0-4.0 keV is shown Fig. S3); (c) Rietveld refinement, background subtracted from the raw data: experimental pattern: data points, calculated pattern: red full line, difference: blue full line; the vertical ticks indicate the Bragg positions for the 8 identified phases, $R_{w p}=17.2, R_{\exp }=29.9$. Only the phases of interest (romarchite, cassiterite and gold) were treated with the Rietveld method (the scale factor from which the wt \% is calculated, unit cell parameters, instrumental zero point and profile parameters were refined). The others were treated with Le Bail refinements (which does not require any structural information except unit cell parameters).

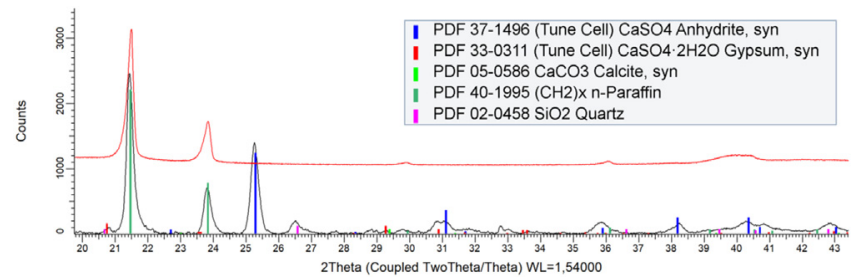

Fig. 4. Black full line: XRPD pattern of spot 2 (only major crystalline phases are shown); red full line at the top: XRPD pattern for a natural beeswax, previously melted and cooled on a sample holder (laboratory diffractometer: D8 Endeavor, Bruker). 
Table 1

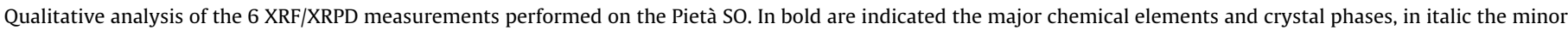

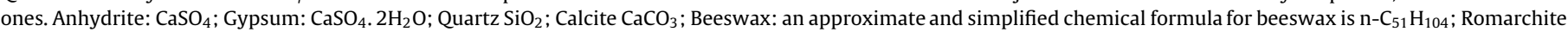

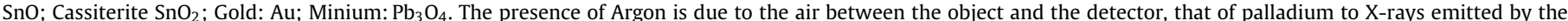
source.

\begin{tabular}{|c|c|c|c|}
\hline $\begin{array}{l}\text { Analysis spot } \\
\text { number }\end{array}$ & $\begin{array}{l}\text { Colour/ } \\
\text { Appearance }\end{array}$ & $\begin{array}{l}\text { Chemical elements identified from XRF } \\
\text { data } \\
\text { (Cu and Pd sources) }\end{array}$ & $\begin{array}{l}\text { Crystalline phases identified } \\
\text { from XRPD data }\end{array}$ \\
\hline 1 & Grey & $\begin{array}{l}\text { S, Ca, }(\mathrm{Ar}), \mathrm{Fe},(\mathrm{Pd}), K, A l, C l, T i, M n, C u \\
S r, P b\end{array}$ & $\begin{array}{l}\text { Anhydrite } \\
\text { Gypsum } \\
\text { Quartz }\end{array}$ \\
\hline 2 & Golden & $\begin{array}{l}\text { S, Ca, Pb, (Ar), Fe, Cu, (Pd), } \mathrm{Au}, A l, C l, K \text {, } \\
T i, M n, S r, S n\end{array}$ & $\begin{array}{l}\text { Anhydrite } \\
\text { Beeswax } \\
\text { Gypsum } \\
\text { Quartz } \\
\text { Calcite }\end{array}$ \\
\hline 3 & Beige & $\begin{array}{l}\text { Ca, Pb, S, (Ar), Fe, Cu, (Pd), Sn, Au, Al, Cl, } \\
K, T i, M n, S r\end{array}$ & $\begin{array}{l}\text { Beeswax }^{\mathrm{a}} \\
\text { Anhydrite } \\
\text { Gypsum } \\
\text { Quartz } \\
\text { Romarchite } \\
\text { Cassiterite } \\
\text { Minium }\end{array}$ \\
\hline 4 & Golden & $\begin{array}{l}\text { Ca, Pb, S, (Ar), Fe, Cu, (Pd), Au, } A l, C l, K \\
T i, M n, S r, S n\end{array}$ & $\begin{array}{l}\text { Beeswax }^{\mathrm{a}} \\
\text { Anhydrite } \\
\text { Gypsum } \\
\text { Quartz }\end{array}$ \\
\hline 5 & Brown & $\begin{array}{l}\text { Ca, Pb, S, (Ar), Fe, Cu, (Pd), Sn, Au, } A l, C l \\
K, T i, M n, S r\end{array}$ & $\begin{array}{l}\text { Gold } \\
\text { Beeswax } \\
\text { Romarchite } \\
\text { Cassiterite } \\
\text { Anhydrite } \\
\text { Gypsum } \\
\text { Calcite } \\
\text { Minium }\end{array}$ \\
\hline 6 & Brown & $\begin{array}{l}\text { Ca, Pb, (Ar), Fe, Cu, (Pd), Sn, Au, Al, S, Cl, } \\
K, T i, M n, S r\end{array}$ & $\begin{array}{l}\text { Beeswax }^{\mathrm{a}} \\
\text { Romarchite } \\
\text { Cassiterite } \\
\text { Gold } \\
\text { Minium } \\
\text { Anhydrite } \\
\text { Gypsum } \\
\text { Calcite }\end{array}$ \\
\hline
\end{tabular}

a This phase is referenced in the PDF4+ database as n-paraffin (PDF 49-1995) but we have shown that beeswax produces the same powder diffraction signal (see $\S 3.2 .1$ ).
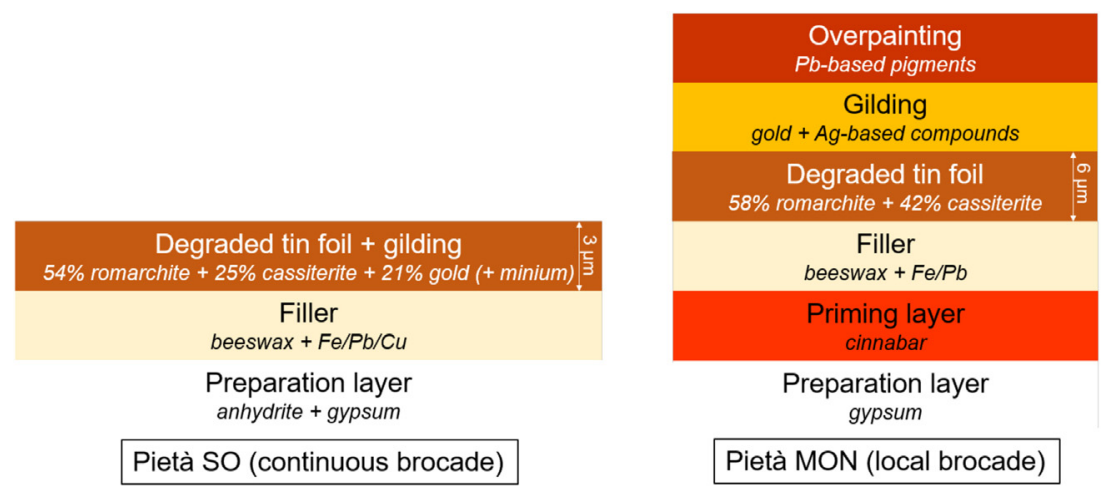

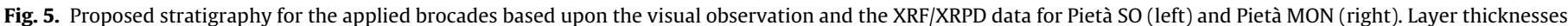
are not to scale. Only major phases/elements are indicated.

tin foil, was obtained by FTIR (Fourier Transform infrared spectroscopy) and/or GCMS (gas chromatography interfaced to mass spectrometry), after the layer-by-layer sampling (if possible) of the representative material from samples prior taken on the artworks [35,37,56-58]. Here, we have chosen to use a non-destructive approach and excluded, in a first step, taking samples. However, we were still able to identify the presence of beeswax from its XRPD signature. We have recorded the XRPD pattern for a natural beeswax (purchased from C.T.S., Italy) on a laboratory diffractometer (D8 Endeavor, Bruker) and checked that it was identical to that referenced as n-paraffin in the PDF4+ database (Fig. 4). Previous studies have already compared the crystal structures of different waxes and shown that recrystallised beeswax has a layer packing similar to the paraffin waxes [59]. Moreover, no Bragg peaks characteristic of lead soaps (lead palmitate or lead stearate) which usually form in saponified oils [60] have been found but we can't exclude the presence of non-saponified oil (and therefore not producing a diffraction signal) in mixture with beeswax.

Another clue of the presence of beeswax (possibly mixed with other organic compounds: resin, oil, glue, proteins... which don't 
diffract X-rays) is the strong fluorescence visible in ultraviolet light which underlines the outline of the pattern (Fig. S4, Supplementary Information), even though the observed colour may be misleading and altered by the surrounding materials [61].

\subsection{Pietà $M O N$}

Five spot analysis have been performed in and around one flaw found in the polychromy of Saint John's mantle (Fig. 2c). One supplementary analysis has been done on the back of the statue, in order to access the preparation layer (spot 1). In the case of this sculpture, due to the presence of overpainting, the interesting points to be analysed are found in hollows and the positioning of the instrument to place the incident beam was therefore very challenging. In addition, emitted and diffracted X-rays can also be absorbed along their path to the detectors by the upper layers of the stratigraphy. The resulting XRF/XRD data are therefore noisier than those of Pietà SO. Nevertheless, the chemical and structural composition of the analysed points could be determined (Table 2). XRF fit for spot 5 and phase identification for spot 4 are given in Supplementary Information (Figs. S5 and S6).

The 6 spots analysis are respectively rich in $\mathrm{S} / \mathrm{Ca}, \mathrm{Hg}, \mathrm{Pb} / \mathrm{Fe}, \mathrm{Sn}$, $\mathrm{Au} / \mathrm{Ag}$ and $\mathrm{Pb}$ (Figs. S7 and S8) which is consistent with the main constituent phases identified by XRPD. Pb and $\mathrm{Fe}$, found in point 3 , are not associated with any crystalline phase but could correspond to the addition of pigments in small quantities in beeswax as already discussed for Pietà SO. Although the presence of overpainting makes the stratigraphy difficult to read, a simplified diagram with 6 layers can be proposed, based on the XRF/XRD results and the visual investigation of the selected zone for the non-invasive analyses:

- Layer 1: the preparation layer, mainly gypsum

- Layer 2: a priming paint layer rich in vermillion (cinnabar $\mathrm{HgS}$ )

- Layer 3: the filler, based on beeswax

- Layer 4: the tin foil, identified by the presence of tin oxides (romarchite: $\mathrm{SnO}$ and cassiterite: $\mathrm{SnO}_{2}$ )

- Layer 5: the gold leaf gilding, characterised by the presence of gold and silver-based compounds (chlorargyrite: $\mathrm{AgCl}$ and Silver sulfide: $\mathrm{Ag}_{2} \mathrm{~S}$ )

- Layer 6: overpainting, rich in lead-based pigments (it may consist of several layers but has not been investigated more precisely)

\section{A possible stratigraphy is suggested in Fig. 5.}

\section{Discussion}

Despite some difficulties (positioning of the instrument, access to in-depth layers), a description of the stratigraphy of the two Pietà could be proposed, based on the results of non-invasive analysis and a careful visual examination of the surface. Even if this description is necessarily more simplified than the one that could be made from the study of cross sections, in particular because very thin layers (gold leaf adhesion or surface varnish in particular) are not or hardly detected, several interesting elements could be highlighted. Using the mobile instrument made it possible to carry out multiple spot analyses: these first results will be used to guide the selection of future sampling zones in order to take the most representative samples of the polychromy.

\subsection{Common technical characteristics}

The different components that make up a "brocade system" were identified in both sculptures: a filler material, a tin-based foil and a gilding. In the two cases, the filler material was identified as beeswax, although a mixture with other organic compounds (resin, oil, glue, proteins...) which don't diffract X-rays, cannot be excluded. X-ray based techniques are clearly not the most suitable to identify non-crystalline organic compounds and further studies will be necessary to clarify the nature of the organic part of the filler. We are also unable at this stage to discuss if the filler has been applied in one or two layers, which can be identical or not, as mentioned by different authors $[34,38,57,58]$. A study of the different types of fillers of applied brocades produced in the Low Countries has been recently published and confirms the presence of beeswax in most of the samples [57]. In most cases, the beeswax was mixed either with oil and/or resin. According to Frinta [58], wax (ou resinwax) filler replaced those composed of gesso because it could be made much more pliable and therefore it followed more easily the complex and deeply recessed curving surfaces. The filler also contains an inorganic part, often in small quantities: black and/or white pigments, red or orange in colour, probably chosen for their colouring and/or siccative power. Here, the presence of minium and/or different elements (iron, copper and lead) at analysis spots rich in beeswax (Tables 1 and 2) could correspond to this addition of pigments. These results have been compared with those published for applied brocades made in other regions. The same constituents and types of mixtures have been found, although an inorganic part based on calcium compounds (calcium carbonate or calcium sulphate) seems to be more common in Spain, Italy and Germany. For example, Rodríguez-López et al. [34,56] showed that, in four of six altarpieces of the Basque region of Gipuzkoa (Spain), the filling masses consisted of calcium sulphate mixtures, mainly gypsum or anhydrite (occasionally with other pigments or additives) and organic materials (protein and/or oil or beeswax). Thus, there seems that for Pietà SO and MON, the nature of the filler corresponds to the expected materials, found for example in the Low Countries. Another common element of both sculptures concerns the tin foil, now degraded into a mixture of two tin oxides: romarchite $(\mathrm{SnO})$ and cassiterite $\left(\mathrm{SnO}_{2}\right)$. According to the mass proportions estimated from Rietveld refinements, the quantity of romarchite is always greater than that of cassiterite: twice for Pietà SO and 1.4 for Pietà MON. To our knowledge, these degradation products had never been identified in applied brocades, probably because the analytical techniques used, like e.g. XRF or scanning electron microscope with energy dispersive $\mathrm{X}$-ray microanalysis system, are unable to distinguish metallic tin from its oxides. In literature, the tin layer is often described as "degraded", based on observations of changes in its colour and appearance, explained by either the structural conversion (known as tin pest) from the "white tin" $(\beta-S n)$ to the "grey tin" $(\alpha-S n)$ which occurs at moderately low temperature (below $13.2^{\circ} \mathrm{C}$ ) or by an oxidation process, without further precision $[33,38,57,62,63]$. Romarchite is cited once by Duran et al. [64] as oxidation product of a tin leaf, used to decorate ceramics in the Cathedral of Seville (tympanon of "Birth portico", 15th century). The only example of identification of romarchite and cassiterite is given by Szmelter et al. [47], in the study of the triptych of the Last Judgement (15th century, National Museum, Gdańsk, probably begun by Rogier van der Weyden and completed by Hans Memling). These compounds are described as the degradation products of a metallic tin plate, used as a support for painting the donor's portrait. The portrait was painted initially on a separate tin plate support, which was subsequently glued, as an insert, on to the original surface. The authors mention the production of donor portraits on tin supports in another triptych, the Seven Sacraments, also carried out by Rogier van der Weyden (Royal Museum of Fine Arts, Antwerp): in this case, metallic tin and cassiterite were observed. The authors assume that the metallic tin foil was oxidized, probably first due to the contact with the paint layers and their binders, and later by the action of the oxygen from the atmosphere. According to them, formation of romarchite is a required step in the oxidation of pure metallic tin to the final most stable phase, cassiterite. We are cur- 
Table 2

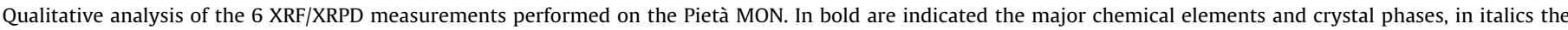

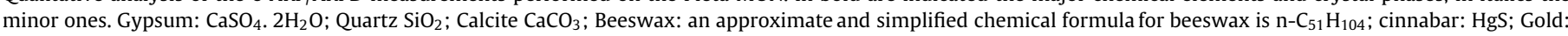

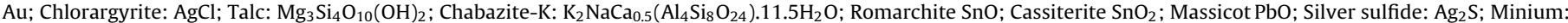
$\mathrm{Pb}_{3} \mathrm{O}_{4}$. The presence of Argon is due to the air between the object and the detector, those of palladium to X-rays emitted by the source.

\begin{tabular}{|c|c|c|c|}
\hline Analysis spot number & $\begin{array}{l}\text { Colour/ } \\
\text { Appearance }\end{array}$ & $\begin{array}{l}\text { Chemical elements identified from XRF } \\
\text { data } \\
\text { (Cu and Pd sources) }\end{array}$ & $\begin{array}{l}\text { Crystalline phases identified from } \\
\text { XRPD data }\end{array}$ \\
\hline 1 & White & $\begin{array}{l}\text { S, Ca, Cl, Fe, Sr, }(A r), K, T i, M n, N i, C u, Z n \\
(P d), H g, P b\end{array}$ & $\begin{array}{l}\text { Gypsum } \\
\text { Calcite } \\
\text { Quartz } \\
\text { Beeswax }^{\mathrm{a}}\end{array}$ \\
\hline 2 & Red-orange & $\begin{array}{l}\mathrm{Hg}, \mathrm{S}, \mathrm{Cl},(\mathrm{Ar}), \mathrm{Ca}, \mathrm{Fe},(\mathrm{Pd}), \mathrm{Au}, \mathrm{Pb}, K, T i \\
M n, N i, \mathrm{Cu}, \mathrm{Zn}, \mathrm{Sr}, \mathrm{Sn}\end{array}$ & $\begin{array}{l}\text { Cinnabar } \\
\text { Gypsum } \\
\text { Calcite } \\
\text { Beeswax }^{\mathrm{a}}\end{array}$ \\
\hline 3 & Beige-golden & $\begin{array}{l}\text { Fe, Pb, S, Cl, (Ar), Ca, (Pd), Sn, Au, Hg, K, } \\
T i, M n, N i, C u, Z n, S r, A g\end{array}$ & $\begin{array}{l}\text { Beeswax }^{\mathrm{a}} \\
\text { Calcite } \\
\text { Cinnabar } \\
\text { Gold } \\
\text { Chlorargyrite } \\
\text { Talc? } \\
\text { Chabazite-K? }\end{array}$ \\
\hline 4 & Brown & $\begin{array}{l}\text { Sn, S, Cl, (Ar), Ca, Fe, (Pd), Au, Hg, Pb, K, } \\
T i, M n, N i, C u, Z n, S r, A g\end{array}$ & $\begin{array}{l}\text { Cinnabar } \\
\text { Romarchite } \\
\text { Cassiterite } \\
\text { Calcite } \\
\text { Gold } \\
\text { Chlorargyrite } \\
\text { Talc? } \\
\text { Massicot } \\
\text { Beeswax }^{\text {a }}\end{array}$ \\
\hline 5 & Golden & $\begin{array}{l}\text { Ag, } \mathrm{Au}, \mathrm{S}, \mathrm{Cl},(\mathrm{Ar}), \mathrm{Ca}, \mathrm{Fe},(\mathrm{Pd}), \mathrm{Sn}, \mathrm{Hg} \\
\mathrm{Pb}, K, T i, \mathrm{Mn}, \mathrm{Ni}, \mathrm{Cu}, \mathrm{Zn}, \mathrm{Sr}\end{array}$ & $\begin{array}{l}\text { Gold } \\
\text { Chlorargyrite } \\
\text { Romarchite? } \\
\text { Silver sulfide } \\
\text { Beeswax } \\
\text { Cinnabar }\end{array}$ \\
\hline 6 & Red-brown & $\begin{array}{l}\mathrm{Pb}, \mathrm{S}, \mathrm{Cl},(\mathrm{Ar}), \mathrm{Ca}, \mathrm{Fe},(\mathrm{Pd}), \mathrm{Ag}, \mathrm{Hg}, K, \mathrm{Ti} \\
\mathrm{Mn}, \mathrm{Ni}, \mathrm{Cu}, \mathrm{Zn}, \mathrm{Sr}, \mathrm{Au}\end{array}$ & $\begin{array}{l}\text { Beeswax }^{\mathrm{a}} \\
\text { Cinnabar } \\
\text { Gold } \\
\text { Massicot } \\
\text { Minium } \\
\text { Calcite } \\
\text { Chlorargyrite }\end{array}$ \\
\hline
\end{tabular}

a This phase is referenced in the PDF4+ database as n-paraffin (PDF 49-1995) but we have shown that beeswax produces the same powder diffraction signal (see $\S 3.2 .1$ ).

rently conducting various experiments to try to better understand the degradation mechanisms of the tin foil and the conditions of formation of tin-oxides: are they coexist in all cases, do their proportions vary, what is the influence of the surrounding layers, is it possible to envisage a galvanic corrosion between gold and tin...? In principle, by using the attenuation law (see $\S 2.2$ ), we are able to estimate the thickness of the layers containing the metallic elements, layer 3 for the Pietà SO (rich in tin and gold) and layer 4 for the Pietà MON (tin-based). We estimated the thickness of layer 3 (Pietà SO) by calculating the attenuation of the emission line of calcium through this layer (by comparing the intensity of the K $\alpha$-line of calcium between the spots 1 and 6 , which corresponds respectively to the value of $I_{0}$, the beam intensity prior to attenuation and $I$, the beam intensity after attenuation, Fig. S2). For this, several hypotheses have to be made and we assumed:

- Calcium is only present in the preparation layer (layer 1)

- Beeswax (layer 2) being an organic material doesn't substantially attenuate the X-rays emitted by the calcium

- Layer 3 contains only romarchite, cassiterite and gold in mass proportions obtained by Rietveld refinement of the XRPD pattern of spot 6 (see Fig. 3c). Layer 3 can thus be considered as a "dummy" material, homogeneous and non-porous, whose density and mass attenuation coefficient can be calculated.
A thickness of about $3 \mu \mathrm{m}$ is obtained. If it is assumed (i) that the thickness of the gold leaf is negligible (it is rated between 0.2 and $0.5 \mu \mathrm{m}$ ) and (ii) the transformation of metallic tin into oxides does not result in a variation in thickness, the value obtained can be compared with the tin foil thicknesses published by Nadolny: 5-80 $\mu \mathrm{m}$ [65] or for applied brocades produced in the Low Countries (between 25 and $50 \mu \mathrm{m}$ ) [57]. In practical, the method can only provide a greatly underestimated value because layer 3 is actually porous and not continuous. Moreover, the presence of calcite at spot 6 , even in minor quantity, is a source of calcium which also leads to an overestimation of the value of $I$. Similarly, we estimated the thickness of the tin-containing layer 4 (Pietà MON) by calculating the attenuation of mercury L $\alpha$-line through this layer (by calculating the ration $\frac{I_{0}}{T}$ between spots 2 and 4, see Fig. S8) and making the same hypotheses:

- Mercury is only present in the layer 2

- Beeswax layer (layer 3) doesn't attenuate the X-rays emitted by the mercury

- Layer 4 (considered as homogeneous and non-porous) contains only romarchite and cassiterite in mass proportions obtained by Rietveld refinement of the XRPD pattern of spot 4 (see Fig. S9).

A thickness of about $6 \mu \mathrm{m}$ is obtained, once again probably greatly underestimated with the assumptions made. Hence, in both 
cases, the estimated thickness of the tin-oxides layer is low (respectively 3 and $6 \mu \mathrm{m}$ ) but this value should be taken as a minimum estimate as it is based on several assumptions which favour its underestimation. The last common point between the two Pietàs is the presence of gilding, although we will see ( $\S 4.2$.) that differences in the nature of the gold leaf can be seen between the two artworks.

\subsection{Differences between the two artworks}

The first difference that can be pointed out between the two sculptures concerns the nature of the preparation layer, deposited on the wood to produce a proper surface for painting and/or decorating. Indeed, if the two ground layers are both calcium sulphate-based, for Pietà SO, it is mainly composed of anhydrite (anhydrous calcium sulfate $\mathrm{CaSO}_{4}$ ), mixed with gypsum (calcium sulfate dihydrate $\mathrm{CaSO}_{4} \cdot 2 \mathrm{H}_{2} \mathrm{O}$ ) whereas for Pietà $\mathrm{MON}$, it is only based on gypsum. There are few references in the literature concerning this layer, probably because it is not considered to be part of the applied brocade, if one assumes that a ready-to-useb̈rocade was glued to the ground layer. Moreover, the composition of this preparation depends on the nature of the support: wood, stone, wall... [31]. Rodríguez-López et al. recently published papers dedicated to the characterization of the preparation layers of six wooden altarpieces from Northern Spain [34,56]. The grounds are always made of calcium sulphate (except one) and in most of the cases, they present two areas: a coarse gesso (a coarse and thick ground layer made of anhydrite with some particles of gypsum) and on the top a fine gesso (a fine and thin ground layer made of gypsum with some particles of anhydrite in the upper zone). The binding medium usually consists of a proteinaceous material, most likely animal glue, mixed with oil. This type of ground structure is known to be rather characteristic of preparations used in southern Europe (Italy and Spain, see for example [66]); a preparation layer composed of calcium carbonate being more expected in Northern Europe, particularly in England, France, and the Low Countries [67]. Only one altarpiece (the triptych of Rentería) presents a ground made of calcium carbonate and the authors used this result to reinforce its historically reported Flemish origin. Here, the ground layer of Pietà SO may correspond to the two-layer preparation described by Rodríguez-López et al. and that of the Pietà MON would comprise only the fine gesso layer. Further studies will be needed to understand this difference, but in any case, the nature of the preparation layer is more indicative of a southern European influence. The second difference concerns the presence of a priming paint layer (vermillion-based) between the preparation layer and the filler in the case of Pietà MON. This difference could be explained by the fact that the way an applied brocade was attached to its supporting surface varied according to its type. As already observed by different authors [24,37], a local brocade (the type observed for the Pietà MON) was directly applied onto a still tacky paint layer (a coloured top layer or an underlayer), often without any other adhesive. On the other hand, a continuous brocade (case of the Pietà SO) was glued to its background with an adhesive. Here, the used analytical techniques were unable to detect this (very thin and probably amorphous and organic) layer of adhesive. The main difference between the materials used in the manufacture of applied brocade is in the choice of the metal for the gilding: only gold has been detected by XRF/XRPD for the Pietà SO, whereas gold is associated with silver for the Pietà MON. The use of pure gold combining with the particular care taken in the preparation of the support is an indication that the Pietà SO is a sculpture with a quality of execution superior to that of the Pietà MON, if not exceptional. For the Pietà MON, XRPD shows that gold is still present in metallic form, unlike silver degraded into chlorargyrite $(\mathrm{AgCl})$ and silver sulfide $\left(\mathrm{Ag}_{2} \mathrm{~S}\right)$. These two compounds have been already described as degradation products of a silver gilded foil known as Zwischgold or "part-gold" [64,68]. Zwischgold is made of two thin sheets of gold and silver hammered together, possibly for economic reasons. Its use is often considered illicit or fraudulent (and banned in Lisbon in 1539 and again in 1572 for the manufacture of artworks [36]) but could also be for aesthetic/artistic purposes and/or for technical reasons [69]. The unambiguous identification of Zwischgold and its distinction with a gold-silver alloy, also identified in ancient "gilded" art objects from European cultural heritage and applied-brocades $[63,38]$, is still challenging because the analytical techniques have to succeed in revealing the presence of two distinct very thin metal layers, of a hundred nanometres each [69]. We are currently engaged in more detailed characterizations of the gilding of the Pietà MON to ensure the presence of Zwischgold. Recently, another assumed example of the use of Zwischgold in the gilding of an applied brocade on another sculpture from the Duchy of Savoy has just discovered and further analysis is currently underway [42].

\section{Conclusion}

Based on the results of non-invasive measurements and with the help of a fine observation of the surface, we have characterized the relief decorations of two Pietà from the ancient Savoy Duchy, stylistically linked to the same artistic centre. We showed that the different materials making up an applied brocade could be identified, even in the case of a largely overpainted sculpture, proving the use of this sophisticated technique of imitating precious textiles in this region at the Late-Gothic and First-Renaissance periods. New elements have been gained, in particular in the characterization of the degradation of this type of decorations, since for the first time the degradation products of the tin foil have been identified and their quantity estimated. A direct identification of the organic material used for the filler (beeswax here) could also be made from the XRPD data. Differences between the two artworks have also been identified: if the preparation layers are both based on calcium sulphate (anhydrite and/or gypsum), the ground of the Pietà SO would correspond to a double layer of gesso, contrary to that of the Pietà MON, which would have only one layer. The presence of a priming paint layer in the case of the Pietà MON may indicate a superimposition of layers specific to local brocades. Lastly, an interesting point concerns the choice of the material used to make the gilding: pure gold for the Pietà SO and probably zwischgold for the pietà MON. It is now necessary to study also the other applied brocades present on these two Pietà. More conventional studies on cross-sections will also have to be carried out to clarify certain points that have not been resolved by this non-destructive but relatively coarse approach, such as the identification of organic compounds in certain very thin layers: in this case, the choice of sampling zones could be guided by the results obtained in a noninvasive manner. It will then be necessary to extend the corpus of works in order to draw more solid and broader conclusions and put them into perspective with the results found in other regions. In the future, by comparing the techniques used to manufacture the applied brocades of a geographically and temporally coherent corpus of works, we will seek to understand how the workshops in charge of making these reliefs were organised, which remains an intriguing question, even for regions where major polychromy workshops have nevertheless been clearly identified (referred to as that of the Geel Master of the Dianthus or that of Master I*T in the Low Countries [70]. For several authors, it seems clear that the technique of applied brocade was too difficult to learn from models or recipe books and required practical instruction from a Master $[37,70]$. Will we ever be able to identify the Master of the Duchy of Savoy? 


\section{Acknowledgements}

The authors are grateful to Sophie Omère, Heritage Curator at the Direction Régionale des Affaires Culturelles Auvergne-Rhône Alpes, for authorising access to the two sculptures. They also thank Sébastien Gosselin, Curator at the musée savoisien in Chambéry (Savoie, France) for allowing the studies on the Pietà SO and Julien Coppier, member of the Académie Florimontane (Annecy) and owner of the castle of Montrottier (Lovagny, Haute-Savoie, France) the studies on the Pietà MON.

This work was financially supported by the French National Research Agency in the framework of the Investissements d'Avenir program (ANR-15-IDEX-02, Cross Disciplinary Program Patrimalp). We thank the support from the Ile-de-France region (DIM Analytics, project IMAPAT) for the funding of the XRD-XRF prototype.

\section{Appendix A. Supplementary data}

Supplementary material related to this article can be found, in the online version, at doi:https://doi.org/10.1016/j. culher.2020.10.012.

\section{References}

[1] P. Ricciardi, UV-visible-NIR reflectance spectrophotometry in cultural heritage: background paper, Anal. Methods 30 (2016) 5894-5896.

[2] Ph. Colomban, The on-site/remote Raman analysis with mobile instruments: a review of drawbacks and success in cultural heritage studies and other associated fields, J. Raman Spectrosc. 43 (2012) 1529-1535.

[3] A.N. Shudar, Portable X-ray fluorescence and archaeology: limitations of the instrument and suggested methods to achieve desired results, in: R.A. Armitage, J.H. Burton (Eds.), Archaeological Chemistry VIII, ACS Symposium Series, American Chemical Society, Washington DC, 2013, pp. 174-193.

[4] M. Alfeld, K. Janssens, J. Dik, W. de Nolf, G. van der Snickt, Optimization of mobile scanning macro-XRF systems for the in situ investigation of historical paintings, J. Anal. At. Spectrom. 26 (2011) 899-909.

[5] Ph. Walter, Ph. Sarrazin, M. Gailhanou, D. Hérouard, A. Verney, D. Blake, Full-field XRF instrument for cultural heritage: application to the study of a Caillebotte painting, X-ray Spectrom. 48 (2019) 274-281.

[6] M. Alfeld, M. Mulliez, P. Martinez, K. Cain, Ph. Jockey, P. Walter, The eye of the Medusa: XRF imaging reveals unknown traces of antique polychromy, Anal. Chem. 89 (3) (2017) 1493-1500

[7] E. Pouyet, N. Barbi, H. Chopp, O. Healy, A. Katsaggelos, S. Moak, R. Mott, M. Vermeulen, M. Walton, Development of a highly mobile and versatile large MA-XRF scanner for in-situ analyses of painted work of arts, X-ray Spectrom. (2020), accepted.

[8] L. de Viguerie, S. Rochut, M. Alfeld, P. Walter, S. Astier, V. Gontero, F. Boulc'h, XRF and reflectance hyperspectral imaging on a 15th century illuminated manuscript: combining imaging and quantitative analysis to understand the artist's technique, Herit. Sci. 6 (2018), 11, http://dx.doi.org/10.1186/s40494-018-0177-2.

[9] M. Alfeld, S. Pedetti, P. Martinez, P. Walter, Joint data treatment for Vis-NIR reflectance imaging spectroscopy and XRF imaging acquired in the Theban Necropolis in Egypt by data fusion and t-SNE, C. R. Phys. 19 (2018) 625-635.

[10] A. Dal Fovo, A. Mazzinghi, S. Omarini, E. Pampaloni, Non-invasive mapping methods for pigments analysis of Roman mural paintings, J. Cult. Herit. 43 (2020) 311-318, http://dx.doi.org/10.1016/j.culher.2019.12.002.

[11] E. Pouyet, S. Devine, T. Grafakos, R. Kieckhefer, J. Salvant, L. Smieska, A. Woll, A. Katsaggelos, O. Cossairt, M. Walton, Revealing the biography of a hidden medieval manuscript using synchrotron and conventional imaging techniques, Anal. Chim. Acta 982 (2017) 20-30.

[12] I. Nakai, Y. Abe, Portable X-ray powder diffractometer for the analysis of art and archaeological materials, Appl. Phys. A 106 (2012) 279-293.

[13] A. Gianoncelli, J. Castaing, L. Ortega, E. Dooryhée, J. Salomon, Ph. Walter, J.L. Hodeau, P. Bordet, A portable instrument for in-situ determination of the chemical and phase composition of cultural heritage objects, X-ray Spectrom. 37 (2008) 418-423.

[14] G. Chiari, P. Sarrazin, M. Gailhanou, Portable XRD-XRF instrument for the study of works of art, Powder Diffr. 23 (2008) 175-186.

[15] A. Mendoza Cuevas, F. Bernardini, A. Gianoncelli, C. Tuniza, Energy dispersive X-ray diffraction and fluorescence portable system for cultural heritage applications, X-ray Spectrom. 44 (2015) 105-115.

[16] J. Castaing, M. Dubus, A. Gianoncelli, B. Moignard, P. Walter, Development of a portable X-ray diffraction/X-ray fluorescence device for non-destructive analysis of works of art, Techne 43 (2016) 79-83.

[17] L. Beck, H. Rousselière, J. Castaing, A. Duran, M. Lebon, B. Moignard, F. Plassard, First use of portable system coupling X-ray diffraction and X-ray fluorescence for in-situ analysis of prehistoric rock art, Talanta 129 (2014) 459-464
[18] S. De Meyer, F. Vanmeert, R. Vertongen, A. Van Loon, V. Gonzalez, J. Delaney, K. Dooley, J. Dik, G. Van der Snickt, A. Vandivere, K. Janssens, Macroscopic X-ray powder diffraction imaging reveals Vermeer's discriminating use of lead white pigments in Girl with a Pearl Earring, Sci. Adv. 5 (2019), eaax1975.

[19] F. Vanmeert, N. de Keyser, A. van Loon, L. Klaassen, P. Noble, K. Janssens, Transmission and reflection mode macroscopic X-ray powder diffraction imaging for the noninvasive visualization of paint degradation in still life paintings by Jan Davidsz de Heem, Anal. Chem. 91 (2019) 7153-7161.

[20] G. Bapst, Etudes Sur l'étain Dans l'Antiquité et au Moyen-Age-Orfèvrerie et Industries Diverses, Masson, Paris, 1884.

[21] Theophili Presbyteri et Monachi, Libri III, Seu Diversarum Artium Schedula, Essai Sur Divers Arts, Livre Premier, XXV and XXVI, Translation by Charles de l’Escalopier J.-A. Toulouse, Paris, 1843.

[22] Cennino Cennini, Il Libro Dell'arte, Le Livre de l'art, Translation by Colette Déroche, Berger-levrault, Paris, 1991.

[23] Tegernsee Manuscript or Liber Illuministarum (late-15th century), Library of the State of Bavaria in Munich (cod. germ. 821), unpublished.

[24] I. Geelen, D. Steyaert, Making applied brocade-recipes and methods, in: Royal Institute for Cultural Heritage (Ed.), Imitation and Illusion, Applied Brocade in the Art of the Low Countries in the Fifteenth and Sixteenth Centuries, Scientia Artis, Brussels, 2011, pp. 65-73.

[25] K.-W. Bachmann, E. Oellerman, J. Taubert, The conservation and technique of the Herlin Altarpiece (1466), Estud. Conserv. 15 (1970) 327-369.

[26] S. Colinart, S. Guillot de Suduiraut, Les Brocarts Appliqués- La Nativité, Technè, 7, 1998, pp. 61-62.

[27] I. Geelen, D. Steyaert, Migrating brocades-the spread of applied brocade throughout Europe, in: Royal Institute for Cultural Heritage (Ed.), Imitation and Illusion, Applied Brocade in the Art of the Low Countries in the Fifteenth and Sixteenth Centuries, Scientia Artis, Brussels, 2011, pp. 49-64.

[28] S. Pagès-Camagna, La polychromie des sculptures brabançonnes du musée de Louvre sous l'œil du microscope, in: S. Guillot de Suduiraut (Ed.), Retables Brabançons des $\mathrm{XV}^{\mathrm{e}}$ et $\mathrm{XVI}^{\mathrm{e}}$ Siècles, La Documentation française, Musée du Louvre, 2002, pp. 103-126.

[29] I. Geelen, D. Steyaert, Imitation and Illusion, Applied Brocade in the Art of the Low Countries in the Fifteenth and Sixteenth Centuries Royal Institute for Cultural Heritage, Scientia Artis, Brussels, 2011.

[30] S. Deschamps-Tan, D. Faunières, P.-Y. Le Pogam, S. Pagès-Camagna, Un Saint Jean de calvaire rouergat, témoin du raffinement et de la signification de la polychromie au début du XVIe siècle, Techne 39 (2014) 122-127.

[31] A.-S. Le Hô, S. Pagès-Camagna, La polychromie de la sculpture médiévale française, XIIe-XVe siècles. Bilan des examens et analyses entrepris au C2RMF, Techne 39 (2014) 34-41.

[32] R. Billinge, L. Campbell, J. Dunkerton, S. Foister, J. Kirby, J. Pilc, A. Roy, M. Spring, R. White, A doubled-sided panel by Stephan Lochner, in: Ashok Roy (Ed.), National Gallery Technical Bulletin 18, National Gallery Publication Ltd, London, 1997, pp. 56-67.

[33] J. Sanyova, Polychromie des retables, in: S. Guillot de Suduiraut (Ed.), Retables Brabançons des XVe et XVI ${ }^{e}$ Siècles, La Documentation française, Musée du Louvre, 2002, pp. 81-101.

[34] A. Rodríguez-López, F. Bazeta Gobantes, Classification of the typologies, techniques and materials of the applied brocades of the altarpieces of Gipuzkoa by means of the analytical techniques of laboratory, in: 9th Int. Conference on NDT of Art 2008 Jerusalem, Israel, 2008 https://www.ndt.net/search/docs.php3?showForm=off\&AuthorID=10186.

[35] A. Rodríguez López, N. Khandekar, K. Eremin, R. Newman, A protocol of analysis for the classification of painting techniques applied to brocades of the altarpieces of Gipuzkoa, in: J. Bridgland (Ed.), Diversity in Heritage Conservation: Tradition, Innovation and Participation, ICOM-CC, Allied Publishers Pvt. Ltd., New Delhi, 2008, pp. 619-625.

[36] A. Arinto, Le Retable Majeur de La Sé Velha de Coimbra et La Polychromie Dans Le Diocèse de Coimbra à l'époque Baroque: Aspects Techniques et Esthétiques, PhD Thesis, University of Lisbon, 2009.

[37] C. Serendan, J. Hradilová, D. Hradil, The imitation of brocade fabrics in late medieval altarpieces from transylvania, in: D. Hradil, J. Hradilová (Eds.), Acta Artis Academica, Praha, 2010, pp. 43-61.

[38] M. Barrio, I. Berasain Salvarredi, Applied-brocade in the altarpiece of the coronation of the Virgin of errenteria, Basque Country, in: S. Litjens, K. Seymour (Eds.), Polychrome Sculpture: Decorative Practice and Artistic Tradition, 2017 pp. 106-115

[39] M. Buyle, A. Bergmans, Découverte, étude et restauration de peintures murales (ca. 1400) en l'église Saint-Jean à Malines, CeROArt 8 (2012), http://dx.doi.org/10.4000/ceroart.2822.

[40] A. Mounier, F. Daniel, Sgraffito, zwischgold et brocart appliqué. La dorure dans tous ses états au sein de quelques peintures murales (XVe et XVIe siècles) du Sud-Ouest de la France, Archosciences 37 (2013) 33-40.

[41] S. Haberer, La Restauration de La Mise au Tombeau de La Cathédrale de Saintean-de-Maurienne, La rubrique des patrimoines de Savoie, 2014, pp. 33-34.

[42] F. Lelong, E. Pouyet, S. Champdavoine, T. Guiblain, P. Martinetto, P. Walter, H. Rousselière, M. Cotte, Des « brocarts appliqués » dans la sculpture savoyarde: vers une caractérisation interdisciplinaire, CeRoArt (2020), to be published.

[43] F. Lelong, S. Champdavoine, E. Pouyet, T. Guiblain, Caractérisation de décors dits "brocarts appliqués " dans la polychromie des sculptures, datées des années 1480-1530, rattachées à l'ancien duché de Savoie, 35, La rubrique des patrimoines de Savoie, 2015, pp. 24-25.

[44] F. Lelong, S. Champdavoine, M. Lefèvre, S. Peurichard, E. Pouyet, C. Terpent, Identification de décors en brocarts appliqués dans la polychromie de sculp- 
tures rattachées à l'ancien duché de Savoie, 36, La rubrique des patrimoines de Savoie, 2015, pp. 8-9.

[45] S. Boisset Thermes, La Sculpture en Savoie: Ateliers, Artistes et Commanditaires à Chambéry et Dans Sa Région (vers 1480-Vers 1530), PhD Thesis, University Grenoble Alpes, 2015.

[46] S. Boisset Thermes, S. Marin, 2013, feux sacrés, Saint antoine le Grand en savoie, in: S. Baiocco, M.-C. Morand (Eds.), Des Saints et des Hommes, Officina Libraria, Milan, 2013, pp. 89-117.

[47] I. Szmelter, Ph. Walter, H. Rousselière, New information provided by multidisciplinary and combined studies, including radiography, XRD and XRF, of the triptych the last judgement from national museum in Gdańsk: rogier Van Der Weyden and Hans memling co-authorship, Opuscula Musealia 2 (2015) 61-73.

[48] L. de Viguerie, H. Glanville, G. Ducouret, P. Jacquemot, P. Anh Dang, Ph. Walter, Re-Interpretation of Old Master practices through optical and rheological investigation: the presence of calcite, C. R. Physique 19 (2018) 543-553.

[49] A.P. Hammersley, S.O. Svensson, M. Hanfland, A.N. Fitch, D. Häusermann, Twodimensional detector software: from real detector to idealised image or twotheta scan, High Pressure Res. 14 (1996) 235-248.

[50] J. Kieffer, V. Valls, N. Blanc, C. Hennig, New tools for calibrating diffraction setups, J. Synchrotron Radiat. 27 (2) (2020) 558-566.

[51] J. Rodríguez-Carvajal, Recent advances in magnetic structure determination by neutron powder diffraction, Phys. B 192 (1993) 55-69.

[52] M. Hellenbrandt, The inorganic crystal structure database (ICSD)-present and future, Crystallogr. Rev. 10 (2014) 17-22.

[53] V.A. Solé, E. Papillon, M. Cotte, Ph. Walter, J. Susini, A multiplatform code for the analysis of energy-dispersive X-ray fluorescence spectra, Spectrochim. Acta B 62 (2007) 63-68.

[54] https://www.nist.gov/pml/x-ray-mass-attenuation-coefficients.

[55] I. Geelen, D. Steyaert, Morphological matters-the type, size, relief and design of applied brocade, in: Royal Institute for Cultural Heritage (Ed.), Imitation and Illusion, Applied Brocade in the Art of the Low Countries in the Fifteenth and Sixteenth Centuries, Scientia Artis, Brussels, 2011, pp. 75-83.

[56] A. Rodríguez, K. Eremin, N. Khandekar, J. Stenger, R. Newman, F. Bazeta, M.T. Escohotado, Characterization of calcium sulfate grounds and fillings of applied tin-relief brocades by Raman spectroscopy, Fourier transform infrared spectroscopy, and scanning electron microscopy, J. Raman Spectrosc. 41 (11) (2010) 1517-1524.

[57] D. Steyaert, J. Sanyova, S. Saverwyns, I. Geelen, C. Glaude, A technological study of applied brocade - the laboratory examination of the applied brocades in the catalogue, in: Royal Institute for Cultural Heritage (Ed.), Imitation and Illusion, Applied Brocade in the Art of the Low Countries in the Fifteenth and Sixteenth Centuries, Scientia Artis, Brussels, 2011, pp. 151-178.

[58] M. Frinta, The use of wax for appliqué relief brocade on wooden statuary, Estud. Conserv. 8 (1963) 136-149.
[59] D.L. Dorset, The crystal structures of waxes, Acta Cryst. B51 (1995) 1021-1028.

[60] F.J. Martínez-Casado, M. Ramos-Riesco, J.A. Rodríguez-Cheda, M.I. RedondoYélamos, L. Garrido, A. Fernández-Martínez, J. García-Barriocanal, I. da Silva, M. Durán-Olivencia, A. Poulain, Lead(II) soaps: crystal structures, polymorphism, and solid and liquid mesophases, Phys. Chem. Chem. Phys. 19 (2017) 17009-17018.

[61] https://aiccm.org.au/national-news/summary-ultra-violet-fluorescentmaterials-relevant-conservation.

[62] F. Daniel, A. Mounier, Alteration of gildings on medieval mural paintings, in: E. Janssen, M. Paris, M. Sawicki, K. Seymour, A. Thorn (Eds.), Multidisciplinary Conservation: a Holistic View for Historic Interiors, ICOM-CC, Rome, 2010 http://www.icom-cc.org/54/document/alteration-of-gildings-on-mediaevalmural-paintings/?id=797\#.Xst97WgzY2w.

[63] I. Crina Anca Sandu, M. Helena de Sá, M. Costa Pereira, Ancient 'gilded' art objects from European cultural heritage: a review on different scales of characterization, Surf. Interface Anal. 43 (8) (2011) 1134-1151.

[64] A. Duran, J.L. Perez-Rodríguez, M.C. Jimenez de Haro, L.K. Herrera, A. Justo, Degradation of gold and false golds used as gildings in the cultural heritage of Andalusia, Spain, J. Cult. Herit. 9 (2008) 184-188.

[65] J. Nadolny, Some observations on Northern European metalbeaters and metal leaf in the late Middle ages, in: R.A. Rush-field, M.W. Ballard (Eds.), The Materials, Technology and Art of Conservation: Studies in Honor of Lawrence J. Majewski on the Occasion of His 80th Birthday, New York, 1999, pp. 134-160.

[66] E. Martin, N. Sonoda, A.R. Duval, Contribution à l'étude des préparations blanches des tableaux italiens sur bois (Contribution to the study of white grounds in Italian panel painting), Estud. Conserv. 37 (1992) 82-92.

[67] R.J. Gettens, E.W. FitzHugh, R.L. Feller, Calcium carbonate whites, artists' pigments, in: A. Roy (Ed.), A Handbook of Their History and Characteristics Volume 2, National Gallery of Art, Washington \& Oxford University Press, Oxford, 1993. pp. 203-226.

[68] M. Eveno, E. Ravaud, T. Calligaro, L. Pichon, E. Laval, The Louvre Crucifix by Giotto-unveiling the original decoration by 2D-XRF, X-ray radiography, Emissiography and SEM-EDX analysis, Herit. Sci. 2 (17) (2014), http://dx.doi.org/10.1186/s40494-014-0017-y.

[69] I. Osticioli, A. Lavacchi, L. Capozzoli, E. Berretti, L. Gallo, C. Berberich, J. Agresti, S. Siano, Novel insights on the study of a fifteenth-century oro di metà/Zwischgold gilding by means of ion and electron microscopy: characterization of the stratigraphy avoiding cross-sections preparation, J. Cult. Herit. 44 (2020) 297-306.

[70] I. Geelen, D. Steyaert, masters of applied brocade - the Geel master of the dianthus, master I*T and other polychromers, in: Royal Institute for Cultural Heritage (Ed.), Imitation and Illusion, Applied Brocade in the Art of the Low Countries in the Fifteenth and Sixteenth Centuries, Scientia Artis, Brussels, 2011, pp. 105-119. 